\title{
Government Spending and People Welfare; in Southeast Sulawesi, Indonesia
}

\author{
Syamsul Alam ${ }^{1}$, La Ode Mustafa Rufiini², And Jamal Bake ${ }^{3}$ \\ ${ }^{1,2,3}$ Lecturer at the Department of Administration, Faculty of Social Sciences and Political Science, \\ University of Halu Oleo, Indonesia
}

\begin{abstract}
-
Developing countries use government spending to influence the level of welfare. In addition to the more decentralized the management of expenditure, these countries have also been systematically shifting the composition of government spending on priority items to boost economic growth, to items having a direct effect on the level of welfare. Using time series data from 2001 to 2011, the study tested the association of various types of government spending to the level of welfare of the people at the local level. Model multivariate timeseries autoregressive integrated moving average is applied to test the association between variables. The study's findings indicate that government spending is positively associated with the level of prosperity. However, not all positively associated, even not all types of government spending were significantly associated with the level of prosperity. Shopping transfer positively associated only with an index of human development, poverty reduction, and the net enrollment rate of primary education; spending on goods and services positively associated only with the physical quality of life index; while the general government expenditure only positively associated with gross domestic product per capita.
\end{abstract}

Keywords: government spending, welfare of the people

Date of Submission: 10 November $2016 \longrightarrow$ Date of Accepted: 05 December 2016

\section{INTRODUCTION}

Developing countries government spending used to affect the level of welfare. Government spending includes the cost of procurement of goods and services issued by all levels of government (Ruggeri, 2005; Allen \& Tommasi, 2001). Governments in these countries pay for goods and services to provide the resources and the conditions for a dignified life of the people. Based on the relationship between the cost for the government to benefit citizens, government expenditures are classified into transfer spending, public spending on goods and services, general government expenditure and government debt interest expenditure Ruggeri (2007).

Management of government expenditure developing countries, including Indonesia, have grown increasingly decentralized, and the case of Indonesia, starting from the application of Law No. 22/1999 on regional governance. During the period 2000-2010, about $30 \%$ to $40 \%$ of total government spending in these countries carried out by local governments, where it differs from the late 1980s until the early 1990s, only about $4.5 \%$ (Boex, 2013). Decentralized management of expenditure to the area give hope for the increasing number of citizens who have the opportunity to enjoy well-being, because the citizens closer to the decision makers and the public service program administrator (Artana, 2007).

Developing countries are also systematically shifted the composition of government spending, the original priority on fostering economic growth item, all items having a direct effect on poverty reduction and the achievement of humanitarian outcomes (Tanzi, 2008; Paternostro et al., 2007). A shift in the composition of spending is important because until now there are still a large number of citizens who do not enjoy welfare. World Development Indicators 2012 (The World Bank, 2012) states, in the countries in question, there are still $22.4 \%$ of the population living on less than 1.25 US dollars per day, and approximately $20 \%$ of school-age children do not finish education basic; and 63 infant deaths per 1,000 live births.

The Indonesian government is extensively using local government spending as the main instrument to influence the level of welfare and other dimensions of public life in the last decade. Approximately $48.3 \%$ of public spending in Indonesia in the period from 2000 to 2010 carried out by the local government (Boex, 2013). However, the public administration in Indonesia has not provided an adequate explanation of the positive association of government spending with the welfare of people and the type of government spending can well predict the level of prosperity. Studies of Prasetiya et al. (2012) used data on the provincial level but uses a classification method spending by sector and focus only on the direct effect of government spending.

Continuing the previous studies in the tradition of the theory of citizen-over-state, and using the classification of government expenditure Ruggeri (2007), this study tested the association of government 
spending to the level of prosperity. During the period 2001-2011, Southeast Sulawesi province has a level of aggregate expenditure amounted to $33.3 \%$ of the regional gross domestic product (GDP). Golden rule of government spending Rowse (2013) is $20 \%$ to $22 \%$. With the aggregate expenditure level, Southeast Sulawesi has per capita aggregate expenditures of Rp 3 million in 2011, compared to the national average of Indonesia in the year, only \$1.8 million (World Bank, 2012).

However, in various indicators of the level of prosperity, Southeast Sulawesi province is still far short of the national average. For example, based on data of 2011, the GDP per capita amounted to Rupiahs 14.07 million; the poverty rate $14.56 \%$; human development index of 70.55 . The average number of rational GRDP per capita (USD 30.81 million); the poverty rate $12.49 \%$; and the human development index (72.64) (Southeast Sulawesi in Figures, 2013). In the context of Southeast Sulawesi, the level of government spending has been high, but the level of welfare of the people is still low. This study is relevant to examine associations to transfer expenditure, spending on goods and services and general government expenditure by level of prosperity

\section{LITERATURE REVIEW}

Theory-over-state citizen stated that government spending is welfare-enhancing because it is controlled by aims to positively influence the welfare of society (Kirchner, 2011; Bernauer and Koubi, 2006; Garrett and Rhine, 2006). However, studies government spending above show inconsistent results.A number of studies (Asghar et al., 2012; Mohammadi et al., 2012; Prasetiya et al., 2012; Jacob et al., 2012; Hwang, 2011; Alam et al., 2010; Guisan and Exposito, 2010) has been tested government spending associated with the welfare of people in developing countries according to the direction of the theory of citizen-over-state. Studies of Prasetiya et al. (2012), Alam et al. (2010), and Guisan and Exposito (2010) provide empirical support for the theoretical proposition citizen-over-state, ie government spending positively associated with the level of prosperity. Studies of Mohammadi et al. (2012), Jacob et al. (2012), and Hwang (2011) did not find sufficient empirical support for the theoretical propositions. In fact, studies of Asghar et al. (2012), Boateng (2012), and Prasetiya et al. (2012) find empirical evidence is ambiguous, ie certain types of expenditure positively associated with the level of prosperity but other types of spending negatively associated with the level of prosperity.

The difference in the results of previous studies can be explained partly by the data used. Except Boateng study (2012) and Prasetiya et al. (2012) that takes the area, previous studies on public spending in developing countries use national or aggregate data across countries. In addition, previous studies generally use a classification method or the traditional sector expenditure. Ruggeri (2007) criticizes the way the classification of expenditure as less sensitive to the effects of direct and indirect changes in the level and composition of government spending. This shows that public administration still require the study of government spending in developing countries based on the way a more accurate classification of expenditure. Referring to the theories of citizen-over-state government spending, the study predicts that, by filing the null hypothesis for the estimation of regression model, as follows:

(1) the GDP per capita (Y1) positively associated with transfer spending (X1), public spending on goods and services (X2) and general government expenditure (X3).

$\mathrm{Y} 1=\beta 1 \mathrm{X} 1+\beta 2 \mathrm{X} 2+\beta 3 \mathrm{X} 3$

$(\mathrm{H} 0: \beta 1+\beta 2+\beta 3=0)$

(2) Equity income (Y2) positively associated with transfer spending (X1) and public spending on goods and services (X2).

$\mathrm{Y} 2=\beta 1 \mathrm{X} 1+\beta 2 \mathrm{X} 2$

$(\mathrm{H} 0: \beta 1+\beta 2=0)$

(3) the physical quality of life index (Y3) positively associated with transfer spending (X1) and public spending on goods and services (X2).

$\mathrm{Y} 3=\beta 1 \mathrm{X} 1+\beta 2 \mathrm{X} 2$

$(\mathrm{H} 0: \beta 1+\beta 2=0)$

(4) Human development index (Y4) positively associated with transfer spending (X1) and public spending on goods and services $(\mathrm{X} 2)$.

$\mathrm{Y} 4=\beta 1 \mathrm{X} 1+\beta 2 \mathrm{X} 2$

$(\mathrm{H} 0: \beta 1+\beta 2=0)$

(5) The poverty rate (Y5) positively associated with transfer spending (X1), public spending on goods and services (X2) and general government expenditure (X3)

$\mathrm{Y} 5=\beta 1 \mathrm{X} 1+\beta 2 \mathrm{X} 2+\beta 3 \mathrm{X} 3$

$(\mathrm{H} 0: \beta 1+\beta 2+\beta 3=0)$

(6) Net enrollment rate of primary education (Y6) positively associated with transfer spending (X1) and public spending on goods and services $(\mathrm{X} 2)$.

$\mathrm{Y} 6=\beta 1 \mathrm{X} 1+\beta 2 \mathrm{X} 2$

$(\mathrm{H} 0: \beta 1+\beta 2=0)$ 
(7) Infant mortality rate (Y7) positively associated with transfer spending (X1) and public spending on goods and services (X2).

$\mathrm{Y} 7=\beta 1 \mathrm{X} 1+\beta 2 \mathrm{X} 2$

$(\mathrm{H} 0: \beta 1+\beta 2=0)$

(8) The maternal mortality rate (Y8) positively associated with transfer spending (X1) and public spending on goods and services (X2).

$\mathrm{Y} 8=\beta 1 \mathrm{X} 1+\beta 2 \mathrm{X} 2$

$(\mathrm{H} 0: \beta 1+\beta 2=0)$

\section{1) Approach}

\section{METHOD}

This study uses a quantitative research approach. Creswell (2003) states that if the problems of the research is to understand the best predictors of an outcome, then a quantitative approach is the best. The use of quantitative methods for testing hypotheses about the relationship between the variables in order to find the association has been a major emphasis in public administration cutting-edge science research. By using a quantitative approach, the research variables measured by numbers and analyzed by statistical procedures.

\section{2) Variable Observations}

The level of prosperity as the dependent variable are translated into 8 sub-variables: 1) the GDP per capita (Y1); 2) Equity income (Y2); 3) the physical quality of life index (Y3); 4) Human Development Index (Y4); 5) The poverty rate (Y5): 6) Net enrollment rate of primary education (Y6); 7) infant mortality rate (Y7); and 8) The maternal mortality rate (Y8). Government expenditures are classified into shopping transfer (X1), public spending on goods and services (X2) and general government expenditure (X3) placed as influential variables.

\section{3) Type of Data}

This study uses time series data from 2001 to 2011. The data used is the government spending on aggregate spending, which is the total of the Southeast Sulawesi provincial government spending, government spending in 12 districts / cities in the province, as well as de concentration funds and sector funds in the province, Government spending in this study was defined as transfer expenditure, public spending on goods and services and general government expenditure, referring Ruggeri (2007). Shopping for interest payments on government debt is not included in the study because the area of Southeast Sulawesi province and the district and the city had yet to spend on it.

Aggregate government expenditure be placed into a panel time series transfer spending, public spending on goods and services and general government expenditure, namely: First, including shopping transfer are: (a) grants and subsidies in the government budget years 2000 to 2002; (b) the results and financial aid in the budget years 2003 to 2006; and (c) expenditure grants, subsidies, social assistance, the results and financial aid in the local budget in 2007 through 2011; Second, including spending on goods and public services are: (a) the sector funds in the government budget from 2000 to 2011; (b) de concentration fund the government budget from 2005 to 2011; (c) development expenditures in local budgets in 2001 and 2002; (d) spending on goods and services and capital expenditures in local budgets in 2003 and 2006; (e) direct expenditure, minus personnel expenses, in local budgets in 2007 through 2011Third, the general government expenditure are: (a) routine expenditures (minus the payment of principal and interest on the loan, pension and relief, subsidy / financial aid) in local budgets from 2001 to 2012; (b) all indirect expenditures (minus interest expenditure) in local budgets in 2003 and 2006; and (c) all indirect expenditures (minus interest expenditure, subsidy, grant expenditures, social assistance spending, spending for the results and financial aid), and personnel expenditure on the part of direct expenditures budget year 2007 to 2011 .

The people's welfare is defined as the achievement of regional economic development and social impact is shown, which is observed through the income per capita, economic well-being, and human well-being. Studies using the idea of welfare of the people of the OECD (2001), OECD (2013) and Forgeard et al. (2011), public welfare indicators consist of income per capita that is substituted with the GDP per capita; Economic well-being elaborated into two indicators of the income distribution and poverty reduction or quality of life indices. Human well-being elaborated into five objective indicators, the human development index, quality of life, physical or poverty, the net enrollment rate of primary education, child mortality and maternal mortality. Measures of central government spending and the welfare of people used different units, namely rupiah for government spending and the GDP per capita; the index number for the physical quality of life index and the human development index; percentages for poverty and the net enrollment rate, and the child mortality ratio, and maternal mortality ratio. For reasons of standardization of data, the entire size of the used figure logarithms, as is typically done on a study that used data is not the same size or different size 


\section{4) Source of Data}

Government spending data collected from the following sources: local budget data on the website of the Directorate General of Regional Financial Balance (DJPK) with http://djpk.depkeu.go.id/datadjpk/131/ address on the home page "Data series> Data Budgets> Data per region "; public finance data master of Southeast Sulawesi province in the Secretariat of the Coordination and Cooperation Research Program Public Expenditure and Capacity Harmonization (PEACH) Research Institute Halu Oleo university; The report APBD realization Southeast Sulawesi province and regency / municipality in the province of the fiscal year 2001 to 2006 at the Provincial Finance Bureau Secretariat Southeast Sulawesi; and the annual publication of Southeast Sulawesi in Numbers 2001 to 2012.

Data on the welfare of people gathered from: (1) the annual publication "Statistics Indonesia" from 2004 to 2012; (2) Development of Some Key Indicators booklet Socioeconomic Indonesia from 2008 until 2012; (3) documents the central statistical agency, poverty data, enrollment rates, the Human development Index, the child mortality ratio, and maternal mortality ratio, old school and illiteracy from 2003 to 2011; (4) "Southeast Sulawesi in Numbers" from 2001 to 2012; (5) the annual publication "Indonesia Health Profile" from 2004 to 2012; and (6) the achievement of millennium development targets on poverty, education and health in Regional Development Planning Agency of Southeast Sulawesi province

\section{5) Procedures Data Analysis and Testing Hypotheses}

This study uses a multivariate time series analysis model with autoregressive integrated moving average (ARIMA), and procedure time series modeler to model and analyze the positive association between variables public spending and welfare of the people. ARIMA model assumptions do not follow the ordinary least squares (OLS) regression methods usual in that in the analysis of this study was not conducted testing of multiple regression assumptions. For this purpose, the device Forecasting SPSS version 21.0 of the IBM SPSS Statistics has provided sufficient time series modeler for estimating exponential smoothing and multivariate models (ARIMA) for time series and make predictions. The data series that has been prepared in excel format defined by yearly to run the analysis with multivariate time series forecasting (trends).

Furthermore, the analysis menu and submenu forecasting, selected method of Expert Modeler to obtain ARIMA or exponential smoothing models are best suited for each dependent variable in the series. Statistics from the estimated model directly removes predictors that are not suitable and instead only show predictors match. Data model parameters for this study is ARIMA $(0,3,0)$ to the GDP per capita, ARIMA $(0,1,0)$ to the physical quality of life index, poverty, education net enrollment rate and maternal mortality rate, and ARIMA ( $0,2,0)$ to model the human development index, income generation and under-five mortality. This form is interpreted to mean that the right model for the entire time series in this study is integrated and not autoregressive or moving average. ARIMA $(0, d, 0)$ is a common form of the model integrated with order $\mathrm{d}$ so that the residuals of ARIMA models which have been white noise, the ARIMA model is most appropriate.

The entire regression model proposed is a regression through the origin (RTO) on the grounds that government spending is never zero. Testing the hypothesis in ARIMA equation similar to that done for regression techniques, using t-test so that in this study the hypothesis 1 to 8 were tested by t-test. Statistical significance level (alpha) of up to $90 \%$ applied for the rejection of the null hypothesis.

\section{RESULT AND DISCUSSION}

Summary of output testing using regression coefficient for testing hypotheses relating to, the estimation model (government spending on the welfare of people) in Southeast Sulawesi obtained as follows:

\begin{tabular}{|c|l|l|}
\hline No & Findings Estimation Model & \multicolumn{1}{c|}{ Explanation } \\
\hline 1 & $\mathrm{Y} 1=-.125 * \mathrm{X} 1+.330 * \mathrm{X} 3$ & $\begin{array}{l}\text { Transfer expenditure associated negatively with the GDP, while the } \\
\text { general government expenditure positively associated with the GDP }\end{array}$ \\
\hline 2 & $\mathrm{Y} 2=-.190 * \mathrm{X} 1$ & Transfer spending negatively associated with income distribution \\
\hline 3 & $\mathrm{Y} 3=.008 * \mathrm{X} 2$ & $\begin{array}{l}\text { spending on goods and services for Government positively associated with } \\
\text { physical people's life quality index }\end{array}$ \\
\hline 4 & $\mathrm{Y} 4=.027 * \mathrm{X} 1-.011 * \mathrm{X} 2$ & $\begin{array}{l}\text { Transfer spending positively associated with the human development } \\
\text { index, but spending on goods and services, to do with the human } \\
\text { development index }\end{array}$ \\
\hline 5 & $\mathrm{Y} 5=.179 * \mathrm{X} 1$ & Transfer spending positively associated with reductions in poverty \\
\hline 6 & $\mathrm{Y} 6=.020 * \mathrm{X} 1$ & $\begin{array}{l}\text { Transfer spending positively associated with primary education enrollment } \\
\text { rate }\end{array}$ \\
\hline 7 & $\mathrm{Y} 7=-.295 * \mathrm{X} 1$ & Transfer spending negatively associated with child mortality rate \\
\hline 8 & $\mathrm{Y} 8=-.222 * \mathrm{X} 1$ & Transfer negatively associated with maternal mortality rate \\
\hline
\end{tabular}


Spending on goods and services not associated significantly with the GDP per capita. Shopping transfers and public expenditure of government associated significantly with the GDP per capita but only general government expenditure associated positive. The null hypothesis first proposed was rejected because two of the three values of $\beta$ (ie, $\beta 1$ and $\beta 3$ ) is different from zero. Statistically, variations in spending on transfers and general government expenditure can explain variations in the GDP per capita. Stationary R-squared of 0.97 from the model indicate a goodness of fit so well used to estimate. The regression equation indicates that the effects of spending transfer is equal to $(-0.125)$, while the effect of general government expenditure amounted to (0.330). Expenditure associated transfer significantly, but negatively, by redistributing income. Spending on goods and services not associated significantly with income distribution. Statistically, variations in spending on goods and services cannot explain variations in income distribution. The regression equation in the model of this study showed that the effect of spending transfer is equal to $(-0.190)$. The null hypothesis was rejected both filed for one of two values $\beta(\beta 1)$ is not equal to zero. Stationary R-squared of 0.50 of the model is relatively small or does not indicate a goodness of fit so it is not good to use in making estimates.

Spending public goods and services associated significantly, while spending on transfers was not associated significantly with the physical quality of life index. The null hypothesis was rejected three proposed for one of two values $\beta(\beta 1)$ is greater than zero. Statistically, variations in transfer spending can explain the variation in the physical quality of life index. The regression equation in the model shows that the effects of public spending on goods and services amounted to (0.008). Stationary R-squared of 0.22 of the model does not indicate a goodness of fit so poorly used for the estimate. ARIMA models detect the presence of an outlier of a time series index of the physical quality of life of the series in 2009. This Outlier cause the data series does not follow a normal distribution or not stationary.

Estimates of outlier of 2009 amounted to -0.005 , or nearly equal to the estimated overall time series Transfer expenditures and goods and public services significantly associated with human development index but only transfer expenditure associated positive. The null hypothesis was rejected four proposed because both the value of $\beta$ ( $\beta 1$ and $\beta 2$ ) greater than zero. Statistically, variations in transfer spending and spending on goods and public services can explain the variation in the human development index. Stationary R-squared of 0.879 of these models indicate a goodness of fit so well used to estimate. The regression equation in the model shows that the effects of transfer spending is equal to $(0,027)$, while the effect of public spending on goods and services is equal to (-0.011).Shopping transfer positively and significantly associated with poverty, but public spending on goods and services and general government expenditure was not significantly associated with poverty. The null hypothesis was rejected for the fifth one of three values $\beta(\beta 1)$ is greater than zero. Stationary R-squared of 0.818 of these models indicate a goodness of fit so well used to estimate.

The regression equation indicates that the effect of transfer spending is equal to (0.179). ARIMA model parameters to detect any differential effects of one's good points on the model and the model of the poverty rate of transfer spending. The differential effect of the points meant that the testing of transfer expenditure associated with the poverty rate is better seen in different time intervals of one year. For example, the positive effects of transfer spending in 2001 will be seen in the reduction of poverty in 2002 Transfer expenditures associated positive and significant, but public spending on goods and services not associated significantly, with net enrollment rate of primary education. The null hypothesis was rejected for the sixth second value $\beta$ ( $\beta 1$ and $\beta 2$ ) is not equal to zero. Stationary R-squared of 0,641 of these models indicate a goodness of fit so well used to estimate. The regression equation indicates that the effect of transfer spending is equal to $(0,020)$. ARIMA model parameters to detect any differential effects of one point are understood that the test for the association between expenditure on transfers to the net enrollment rate of primary education is better viewed in different time intervals of one year. Effect of transfer spending in a given year will be seen on the achievement of primary education enrollment rate next year.

Transfer expenditures negatively and significantly associated with child mortality, but public spending on goods and services not associated with a significant mortality rate. The null hypothesis was rejected seventh because one of the two values of $\beta$ ( $\beta 1)$ is not equal to zero. Stationary R-squared of 0.349 of the model does not indicate a goodness of fit so poorly used for the estimate. The regression equation indicates that the effect of transfer spending is equal to (0.295). ARIMA model parameters to detect the differential effects of two points which meant that the test for the association between shopping transfer with better mortality rate seen in a different interval of two years. Effect of transfer spending in a given year will be seen on achieving the child mortality rate in two years later Transfer expenditures negatively and significantly associated with maternal mortality, but spending on goods and public services not associated significantly with maternal mortality. The null hypothesis was rejected due to one of two values $\beta(\beta 1)$ is not equal to zero. Stationary R-squared of 0.869 of these models indicate a goodness of fit so well used to estimate.

The regression equation showing the effect of transfer expenditure amounting to -0.222. ARIMA models detect the presence of one outlier of time series in maternal mortality Outlier's series in 2008. In 2008 the maternal mortality rate is causing the data series does not follow a normal distribution or not stationary. In 
addition, the ARIMA model parameters also detect any differential effects of one point on that model is understood that the test of a positive association transfer spending for maternal mortality will be better seen in different time intervals of one year to the next.

\section{DISCUSSION}

This study follows the theoretical guidance of citizen-over-state government spending. The main purpose of research is to test the hypothesis of a positive association between government spending to the level of prosperity in Southeast Sulawesi. In contrast to other studies based on sector manner and traditional classification of expenditure, the study was based on how the classification of transfer spending, public spending on goods and services and general government expenditure. How this classification is claimed to be more sensitive to the effects of direct and indirect effects of government spending. Based on the theory of citizenover-state, the study anticipates a positive association with the government spending the people's welfare.

Not as anticipated, the results of statistical analysis for the Southeast Sulawesi in 2001-2011 provide empirical support only for a fraction of the theoretical arguments citizen-over-state. The findings for the Southeast Sulawesi citizen theory only supports the argument-over-state with respect to the positive association between shopping transfer to the human development index, poverty, and the net enrollment rate of primary education; positive association between public spending on goods and services with the physical quality of life index; and a positive association between general government expenditure with the GDP per capita. Previous empirical literature (Hong and Ahmed, 2009; Barrientos and Scott, 2008) has confirmed the argument.

On the other hand, transfer expenditure associated negatively with the GDP per capita, income generation, child mortality and maternal mortality rates; public spending on goods and services associated negatively with the human development index in the Southeast. Negative association between the two types of government spending in various indicators of people's welfare is not anticipated by the theory of citizen-overstate. There has been no previous empirical literature that shows a negative association between spending transfers and goods and public services with some indicators of well-being. Meanwhile, the empirical literature History that shows the association of negative public spending with some indicators of well-being (Asghar et al., 2012; Mohammadi et al., 2012; Jacob et al., 2012; Hwang, 2011) entirely using the method of classification of shopping sector and traditional. Southeast Sulawesi case shows that transfer spending is not associated significantly with the physical quality of life index; public spending on goods and services not associated significantly with the GDP per capita, income distribution, poverty, the net enrollment rate of primary education, child mortality and maternal mortality rates; and general government expenditure was not significantly associated with poverty. The absence of any association between the three types of government spending in various indicators of people's welfare is not anticipated by the theory of citizen-over-state. Previous empirical literature has not investigated the association between these variables, except some empirical literature (Asghar et al., 2012; Taban, 2010) that all use the classification method and the traditional sector expenditure

Expenditures transfer is used for financial aid and subsidies to local subordinates, and since 2007 was allocated also for the education and health sectors as well as block grants to villages and sub-districts. Issues regarding the transfer spending in Southeast Sulawesi are the low level of expenditure. Transfer expenditure 2001-2011 period includes an average of only 3.89\% of total government spending, compared for example with cash transfer spending in Mexico is about $12 \%$ of total government expenditure (Bianchi and Bobba, in Bazzi et al., 2013). With a low level of transfer spending, the government has not been able to perform allocations for productive economic sectors and increasing entrepreneurial activity among recipients that do not provide a positive effect and is more pronounced in the GDP per capita and income distribution in Southeast Sulawesi.

Spending public goods and services over the period 2001-2011 covers 56\% of total government spending. The majority of spending on goods and public services absorbed mainly in the sectors of education and health sectors. Past studies (Hassan, 2008) show that spending for agricultural development and rural infrastructure have the greatest effect on the welfare of the mass is. The allocation of public spending on goods and services in Southeast Sulawesi oriented public consumption that reinforces short-term expediency. This is different from the model Sennoga and Matovu (2010) and GANELLI and Tervala (2007), which emphasizes productive public infrastructure that has positive welfare implications in the long term. Weakness aspect expenditure structure is made worse by the low level of use of public goods and services provided through government spending. For example, pregnant women and childbirth in the fourth delivery and so on, on the poor, they tend to use the services of traditional birth attendants instead of public health facilities (World Bank, 2012).

General government expenditure during the period 2001-2011 covers $43 \%$ of total government spending in Southeast Sulawesi and the majority used for shopping salaries and employee benefits, legislators, and local leaders. The level of general government expenditure reflects the high level of prosperity of the household high, relative to other groups. Government officials, including the middle class, according to the criteria of the World Bank's middle class-those who spend their money amounting to 2 dollars to 20 US dollars per day (Suweda, 
2012). The positive association between expenditure on public administration with the GDP per capita can be explained by a behavioral model of household spending. General behavior of the middle class consumer spending in Indonesia is pleased to products that offer greater comfort, such as household goods are durable, tooling, electronics, and automobiles (Hatta,2013).

This phenomenon provides a good climate for economic growth and consequently growth in GDP per capita. Theory citizen-over-state just anticipating has positive association with the government spending level of prosperity. Case in Southeast Sulawesi, years 2001-2011 showed, not all types of government spending positively associated with all the indicators of people's welfare. In fact, not all types of government spending significantly associated with indicators of the level of prosperity. Structural model citizen-over-state still needs to elaborate government expenditure variable that obscure or negate the positive association of government spending with the welfare of people in developing countries. Governments in developing countries need to be more careful in determining the prioritization of expenditures to public welfare objectives could be realized in line with the increase in government spending itself.

\section{CONCLUSION}

Government spending is positively associated with the level of prosperity, however, not all types of government spending positively associated with the level of prosperity. In fact, not all types of government spending was significantly associated with the level of prosperity. Transfer expenditures associated positively with more indicators of the level of prosperity rather than spending on goods and services of public and general government expenditure. Implications of the study showed the need for the elaboration of the variables government spending itself and the design selection policy of government spending that is more sensitive to the goals of social welfare in the long term. Further studies with a number of larger observation unit, verifying the consistency model of association between the level of government spending livelihoods of our people.

\section{REFERENCES}

[1] Alam, S., Sultana, A., and Butt, M.S., 2010. Does Social Expenditures Promote Economic Growth? A Multivariate Panel Co integration Analysis for Asian Countries. European Journal of Social Sciences, Vol. 14, No. 1, 44-54.

[2] Allen, R., and Tommasi, D. (Eds.), 2001. Managing Public Expenditure: A Reference Book for Transition Countries. Paris: OECD.

[3] Artana, Daniel A., 2007. Are Latin-American Countries Decentralized? Buenos Aires: Fundacion de Investigaciones Economica Latinoamericanas. Working papers 92, FIEL. https://ideas.repec.org/e/c/par184.html, diakses 24 Oktober 2015.

[4] Asghar, N., Hussain, Z., and Rehman, Hafeez U., 2012. The Impact of Government Spending on Poverty Reduction: Evidence from Pakistan 1972 to 2008. African Journal of Business Management, Vol. 6 (3), 845-853.

[5] Bank Dunia, 2012. Analisis Keuangan Publik Provinsi Sulawesi Tenggara 2012: Kinerja Pelayanan Publik dan Tantangan Pembangunan di Bumi Haluoleo. Jakarta: Kantor Bank Dunia.

[6] Barrientos, A., and Scott, J., 2008. Social Transfers and Growth: A Review. Working paper 52. Brooks World Poverty Institute, Manchester. (Online), (http://www.bwpi.manchester.ac.uk/). Diakses 17 Februari 2016.

[7] Bazzi, S., Sumarto, S., and Suryahadi, A., 2013. It's All in the Timing: Cash Transfers and Household Expenditures in a Developing Country. (Online), (www.smeru.or.id/report/workpaper/), diakses 17 Februari 2016.

[8] Bernauer, T., and Koubi, V., 2006. States as Providers of Public Goods: How Does Government Size Afect Environmental Quality? Working Paper No. 14. Universität Zürich, Center for Comparative and International Studies (CIS).

[9] Boateng, N.A., 2012. Public Expenditure Management and Education Outcomes: Micro-evidence from Primary Schools and Public Officials in Gauteng and North West Provinces, South Africa. A PhD thesis in Public Law, Johannesburg: University of Witwatersrand.

[10] Boex, J, 2013. Analyzing the Role of the Local Public Sector in Achieving Sustainable Development: Does More Spending at the Local Level Result in Better Development Outcomes? An Analysis of the Vertical Allocation of Public Sector Resources in Ten Developing Countries. www.urban.org/.../LPS_Finance_July201...

[11] Creswell, J. D., 2003. Research Design: Qualitative, Quantitative, and Mixed Methods Approaches. London: Sage Publications.

[12] Fan, S., Huong, P.L., and Long, T.Q., 2000. Government Spending and Poverty Reduction in Vietnam. Project report prepared for the World Bank. International Food Policy Research Institute, Washington DC.

[13] Forgeard, M. J. C., Jayawickreme, E., Kern, M. \& Seligman, M. E. P., 2011. Doing the right Thing: Measuring Wellbeing for Public Policy. International Journal of Wellbeing, 1(1), 79-106. doi:10.5502/ijw.v1i1.15

[14] Ganelli, G., and Tervala, J., 2007. Public Infrastructures, Public Consumption, and Welfare in a New-Open-Economy-Macro Model. International Monetary Fund (IMF) Working Paper, WP/07/67.

[15] Garrett, Thomas A., and Rhine, Russell M., 2006. "On the Size and Growth of Government". Federal Reserve Bank of St. Louis Review, January/February 2006, pp.13-30.

[16] Guisan, M., and Exposito, P., 2010. Health Expenditure, Education, Government Effectiveness and Quality of Life in Africa and Asia. Regional and Sector Economic Studies, Vol. 10 (1), 115-126.

[17] Hassan, G.M. 2009. Public Expenditure, Employment and Poverty in Bangladesh: An Empirical Analysis. Draft of the research report. (Online), (www.undp. org.bd/.. ./pub\%20exp.pd...), diakses 12 Februari 2016.

[18] Hatta, 2013. Pola Konsumsi Kelas Menengah Indonesia Berubah. (Online pada www.republika.co.id > ekonomi > Ritel), diakses 6 Maret 2016.

[19] Hong, H., and Ahmed, S., 2009. Government Spending on Public Goods: Evidence on Growth and Poverty. Economic \& Political Weekly, August 1, Vol. XLIV, No. 31, 102-108.

[20] Hwang, J., 2011. A Cross-Country Analysis of Human Capital Inequality and the Composition of Education Expenditure. European Journal of Social Sciences, Volume 24, Number 1, 97-101.

[21] Kirchner, S., 2011. Why Does Government Grow? CIS Policy Monographs PM117, Centre for Independent Studies (Australia). 
[22] Mohammadi, T., Maleki, B., and Gashti, Hadi P., 2012. The Effect of Government Expenditure Composition On Economic Growth: Evidence on ECO Countries. Economics and Finance Review, Vol. 2(5), 14-21.

[23] OECD (Organization For Economic Co-Operation And Development ), 2013. "Measuring Well-Being For Development." 2013 OECD Global Forum on Development, 4-5 April 2013, Discussion Paper For Session 3.1 (Online), (www.oecd.org/site/oecdgfd/) diakses 3 Juni 2016.

[24] OECD (Organization For Economic Co-Operation And Development ), 2001. The Well-being of Nations: The Role of Human and Social Capital. Paris: OECD.

[25] Paternostro, S., Rajaram, A., and Tiongson, Erwin R., 2007. Does the Composition of Public Spending Matter? Oxford Development Studies, (35) 1, 47-82.

[26] Prasetiya, F., and Pangestuty, Farah W., 2012. Linkages Between Public Sector Expenditure on Economic Growth and Rural Poverty of Indonesia. Journal of Basic and Applied Scientific Research, 2(3), 2347-2353.

[27] Rowse, M., 2013. Public Spending Must Follow the Golden Rule”: The Budget's Unanswered \$68 billion Question. (Online), (http://www.rowse.com. hk/budget question.htm), diakses 13 Maret 2016.

[28] Ruggeri, G., 2005. Public Expenditure Incidence Analysis. In Public Expenditure Analysis. Anwar Shah (Editor). Washington DC: The International Bank for Reconstruction and Development/The World Bank, pp. 1-32.

[29] Sennoga, E. B., and Matovu, J.M., 2010. Public Spending Composition and Public Sector Efficiency: Implications for Growth and Poverty Reduction in Uganda. Economic Policy Research Centre. Research Series No. $66 . \quad$ (Online), (http://www.searchworks.stanford.edu/...), diakses 12 Februari 2016.

[30] Shah, A., and Shah, S., 2006. The New Vision of Local Governance and the Evolving Roles of Local Governments, in Local Governance In Developing Countries, Public Sector Governance And Accountability Series, Edited by Anwar Shah. Washington, D.C.: The World Bank, pp. 1-46

[31] Suweda, I Ketut, 2012. Kelas Menengah dan Perilaku Konsumtif. (ekonomi.kompasiana.com/.../2012/../17/), diakses 13 Maret 2016.

[32] Taban, S., 2010. An Examination of the Government Spending and Economic Growth Nexus for Turkey Using the Bound Test Approach. International Research Journal of Finance and Economics, 48, 184-193.

[33] Tanzi, V., 2008. The Role of the State and Public Finance in the Next Generation. OECD Journal on Budgeting, Volume 8 - No. 2 , $1-27$.

[34] The World Bank, 2012. World Development Indicators 2012. Washington, D.C., The International Bank for Reconstruction and Development/ The World Bank.

[35] Yaqub, J.O, Ojapinwa, T.V., and Yussuff, R.O., 2012. Public Health Expenditure and Health Outcome in Nigeria: The Impact of Governance. European Scientific Journal, June edition, Vol. 8, No.13, 189-201. 